\title{
Narrative review: Epidemiology and acting mechanisms of risk factors of hepatocellular carcinoma
}

\author{
Pengcheng $\mathrm{Li}^{*}$ \\ The Medical School, The University of Queensland, QLD 4006, Australia
}

\begin{abstract}
Hepatocellular carcinoma is a main human malignant primary liver tumour. The incidence of hepatocellular carcinoma differs among geographic regions, ethnic groups, genders and ages. Approximate $80 \%$ of hepatocellular carcinoma cases can be attributed to hepatitis B and C virus infections. Hazardous alcohol consumption, obesity, dietary aflatoxin B1 exposure and hemochromatosis are also significantly associated with development of HCCs. These risk factors alter DNA, modify protein or induce oxidative stress, leading to malignant transformations of hepatocytes.
\end{abstract}

\section{Introduction}

Hepatocellular carcinoma (HCC) is the fifth most prevalent human cancer [1,2]. Nearly 1 million deaths are caused worldwide by HCC each year [3]. Moreover, the worldwide incidence of HCC is increasing by $4.6 \%$ per annum $[2,4]$. Mechanisms of hepatic carcinogenesis are incompletely understood, so that prevention, early detection and treatment of HCCs is still difficult [5-7]. Identifications of risk factors and acting mechanisms of these risk factors are help to decipher the enigma of HCC.

\section{Hepatocellular carcinoma}

HCC is an important primary liver cancer. HCC cells originate in hepatic cells and resemble normal hepatocytes, but the cancer cells lose functions of hepatocytes, and grow abnormally [8,9]. Cancers, originated other hepatic cells, are also called as primary liver cancers. These primary cancers include cholangiocarcinoma, angiocarcinoma, hepatoblastoma and lymphoma. Cholangiocarcinoma develops from the bile ducts [10]. Aetiology of cholangiocarcinoma is chronic inflammation of the biliary epithelium [11]. Fibrolamellar carcinoma accounts for approximately $1 \%$ of all cases of liver cancers [12]. The aetiology of fibrolamellar carcinoma is not known [9]. Hepatoblastoma arises from incompletely differentiated hepatocyte progenitors or stem cells and comprises approximately $1 \%$ of all childhood malignant tumours [13]. Among primary liver cancers, $\mathrm{HCC}$ is the most prevalent, cholangiocarcinoma is the second, and other primary liver cancers are rare [8].

Livers also contain metastatic liver cancers. Metastatic liver cancers arise from cancer cells that spread to the liver, but start in other organs, such as a colon, pancreas, stomach, ovary, kidney, lung or breast [14]. Most liver cancers are metastatic. However, among cirrhotic patients, primary liver cancers account for $77 \%$ of malignancies [8].

\section{Different frequencies of hepatocellular carcinoma in different regions}

The incidence of HCC varies between geographic regions and ethnic groups. Approximately $80 \%$ of HCCs occur in Asia (China,
Hong Kong, Taiwan, Korea, and Japan) and sub-Saharan Africa (Mozambique and South Africa) [15]. Intermediate incidences occur in Eastern Europe, Southern Europe, the Caribbean, Central America and Western Asia. HCCs are relatively rare in Western Europe and North America [16]. Among ethnic groups, the incidence of HCC is the highest among Asians; intermediate among African-Americans and Hispanics; and lowest rate among Caucasians [17]. The frequency of HCC also varies within countries and ethnic groups [18]. For example, in China, the highest incidence is in the north-eastern and south-eastern coastal provinces whereas the incidence is lower within inner western regions [18]. A similar situation occurs in Mozambique where the highest incidences are in the coastal town of Inhambane [19].

The increase in incidence of HCC in many developed countries, including western European nations, has been attributed to an increase in injection drug use, leading to the spread of hepatitis $C$ virus infection in youths, and chronic alcohol consumption in adults [20-22]. Conversely, HCC cases are decreasing in many developing countries where the incidences has previously been high due to wide usage of the HBV vaccine in children [23].

HCC is an uncommon cancer in Australia, in which incidence of this cancer is the $18^{\text {th }}$ most common and mortality $11^{\text {th }}$ among all types of diagnosed cancers in 2007 [21]. However, there has been a significant increase in the incidence and mortality of primary liver cancer, the majority of which (approximately 80\%) are HCCs. Between 1982 and 2007 the incidence of HCC increased approximately three fold (from 1.8 to 5.2 new cases per 100000 population/ year) while HCC mortality doubled (from 2.3 to 4.9 deaths per 100000 population/ year) [21].

Correspondence to: Dr. Pengcheng Li, The Medical School, The University of Queensland, QLD 4006, Australia; E-mail: Pengcheng.li@uqconnect.edu.au

Key words: hepatocellular carcinoma, epidemiology, risk factors, genotoxicity, oxidative stress

Received: March 08, 2016; Accepted: April 18, 2016; Published: April 22, 2016 


\section{Risk factors of hepatocellular carcinoma}

HCC is strongly associated with liver cirrhosis and chronic liver inflammation. Hepatitis B and hepatitis $C$ are main aetiological agents of HCC. About $80 \%$ of HCC cases worldwide are associated with chronic infections with HBV and HCV [24]. Other aetiological agents of HCC are alcohol, aflatoxin B1, diabetes, non-alcoholic fatty liver disease, obesity, tobacco, vinyl chloride and thorium dioxide [25], and some inherited metabolic diseases including hemochromatosis, tyrosinemia and $\alpha$-l-antitrypsin deficiency. Within these disease groups, ethnicity, male gender and age remain important risk factors [26].

\section{Cirrhosis}

Approximately $80 \%$ of HCCs occur in a cirrhotic liver, with up to $20 \%$ occurring in non-cirrhotic or normal livers [27,28]. Some HCC in non-cirrhotic livers still occur in association with liver fibrosis, steatosis or liver cell dysplasia [29]. Cirrhosis has nearly the same causative agents as HCC. For example, most HCCs associated with cirrhosis are also associated with viral hepatitis $B$ [30,31] and C [32], and alcohol abuse [33]. In Asia and Africa, hepatitis B and $C$ are the major risk factors of liver cirrhosis, while in the western world, alcohol is a major risk factor for cirrhosis [34,35]. Obesity [36,37], haemochromatosis [38] and autoimmune hepatitis [39] are also risk factors for cirrhosis.

\section{Hepatitis B virus}

Hepatitis B virus infection is the most major risk factor of HCC. $53 \%$ of worldwide HCC cases attributed to this infection [40]. The association between HBV and HCC was first recognised in the 1970's $[25,41]$. At that time, studies found that the risk of developing HCC was higher in patients with hepatitis B virus surface antigen (HBsAg) compared to patients without HBsAg [42,43]. The World Health Organization reported in 2000 that worldwide, approximately 2 billion people have been infected with the hepatitis B virus, with more than 350 million of them chronic carriers [44]. Cases of HCCs associated with hepatitis B virus infection are the most prevalent in India, Singapore and Mongolia, [40]. Hepatitis B associated HCCs have the second highest prevalence in Korea, China, and Vietnam, Turkey, Thailand, Greece, Pakistan, Peru, Brazil and most African countries [41]. However, in western countries the prevalence of chronic hepatitis $\mathrm{B}$ virus infection is relatively low [45]. The incidence of HCC has been shown to be significantly reduced following immunization of infants with HBV vaccines in the 1980's [46]. In addition, antiviral therapy against Hepatitis B virus also appears to reduce the risk of HCC $[47,48]$.

$\mathrm{HBV}$ is a DNA virus of the Hepadnaviridae family [49], which is the smallest circular DNA of known human viruses [50]. Possible mechanisms of hepatocarcinogenesis related to HBV include insertion of HBV DNA into the genome of hepatocytes, oncogenic effects of HBx protein and oxidative stress induced by immune response to HBV. HBV encodes the 154 amino acid HBx protein [51]. Genomic integration of HBV into the DNA of host cells occurs in most HCCs associated with $\mathrm{HBV}$, but is rare in non-tumour tissues $[52,53]$. The process of $\mathrm{HBV}$ viral integration is enhanced by chronic inflammation [54], and exposure to oxidative stress [55]. Integration of the HBV viral DNA into hepatocyte genome induces genetic instability [56,57]. Furthermore, the HBx protein can interfere with DNA repair [58], and with transcription and signalling pathways [59]. These alterations in turn enhance the malignant transformation of hepatocytes [59].

\section{Hepatitis C virus}

Hepatitis $\mathrm{C}$ virus infection is another major risk factor for HCC, being associated with $25 \%$ of all cases [41]. HCC cases caused by HCV infection comprise approximately $50 \%$ of HCC cases in the United States [60], 59\% in Mexico [61], 74\% in Italy [62,63], 75\% in Spain [64], $53 \%$ in India [64], and $88 \%$ in Japan [65]. However, the rate is 4.28 $\%$ in China, $10 \%$ in Hong Kong, $10 \%$ in Korea, $2 \%$ in Malaysia, $13 \%$ Singapore and $15 \%$ in Thailand [18]. The World Health Organization estimated that there are currently 170 million people chronically infected with HCV in the world [66]. The prevalence of HCV is high in the Middle East, particular in Egypt; but low in Europe, Northern America, Africa, and South East Asia [67]. In the United States, 1.6\% of national population has anti-HCV antibodies. Nearly $50 \%$ of have a history of injection drug use, or other significant risk factors such as blood transfusion [68]. In patients with HCV, additional risk factors for HCC include older age [69] and male gender [70]. Co-infection of HCV with HBV may increase the risk for developing HCC [71], although not all studies have found this [72]. HCV infection results in chronic liver inflammation, in which fibrosis occurs and progresses to cirrhosis and HCC [73].

The incidence of hepatitis $\mathrm{C}$ infection in people living in Australia declined from 57.5 new cases per 100000 population in 2007 to 45.7 news cases per 100000 population in 2011 [74]. It has been estimated that by the end of 2011, approximate 304000 Australians had been exposed to HCV, with the majority of these (estimated to be 226700 ) going on to develop chronic hepatitis $\mathrm{C}$ infection with varying degrees of liver injury [74].

Hepatitis $\mathrm{C}$ virus is a RNA virus that belongs to the Flaviviridae family [75]. It is composed of a $9.6 \mathrm{~kb}$ RNA strand [76], three structural proteins (core protein, envelope 1 and 2) and seven non-structural proteins (p7, NS2, NS3, NS4A, NS4B, NS5A, and NS5B) [77]. The viral RNA of HCV does not integrate into the genome of hepatocytes as HBV does, but structural and non-structural proteins of HCV contribute to malignant transformation of hepatocytes [78]. Another possible mechanism involved in malignant transformation of hepatocyte is oxidative stress caused by chronic HCV infection [79]. Thus, HCV infects hepatocyte which initiates an immune response. Subsequently, inflammatory cells release ROS and RNS which damage DNA, protein and lipid, facilitating the development of HCC. In summary, HCV exerts important effects in malignant transformation of hepatocytes but the molecular mechanisms are still unclear.

\section{Chronic alcohol consumption}

Chronic alcohol consumption increases the risk of HCC in proportion to alcohol intake. A number of cancers are linked to alcohol consumption including primary cancers of the liver, colon, rectum, breast, oral cavity, oesophagus and larynx. Another study of women in the United Kingdom found that while chronic alcohol consumption increased the risk of liver cancer, it reduced the risk of other cancers including thyroid, non - Hodgkin lymphoma and renal cell [80]. Studies have shown that alcohol alone is not genotoxic [81]. However, alcohol acts synergistically with other risk factors to increase the risk of HCC [82]. Chronic alcohol consumption increases the risk of HCC in patients with coexisting hepatitis B [83], hepatitis C $[82,84]$ and haemochromatosis [85]. Worldwide, $3.6 \%$ of all cancers and $3.2 \%$ of all deaths per year are attributed to chronic alcohol consumption [86]. In addition to cancers, chronic alcoholism also induces steatosis, steatohepatitis, hepatic fibrosis and cirrhosis [87].

The exact hepatocarcinogenesis mechanisms induced by chronic alcohol consumption are not known. It is currently believed that alcohol is involved in malignant transformation of hepatocytes via 
a series of direct reactions with hepatocyte molecules and activation of the immune response. Alcohol is oxidized to yield acetaldehyde which can bind DNA to form DNA adducts [88]. Alcohol also interferes with methyl group transfer and may alter gene expression $[89,90]$. Most importantly, alcohol triggers chronic liver inflammation which generates ROS [91], RNS [92] and inflammatory cytokines [93]. Oxidative stress results in damage of DNA, protein and lipid of hepatocytes. Inflammatory cytokines regulate immune response of inflammatory cells, and growth, differentiation and proliferation of hepatocytes. Thus, alcohol induces malignant transformation of hepatocytes via direct genotoxicity of alcohol, and indirectly via oxidative stress and cytokine release from an activate immune response.

\section{Iron overload}

Hemochromatosis $(\mathrm{HH})$ is a genetic disease that leads to iron overload, with a prevalence of $0.2-0.5 \%$ among Caucasians [94,95]. In Australia, the prevalence of $\mathrm{HH}$ is approximately 0.5\% [96]. The incidence of HCC among HH patients is approximately 20 - 200 fold higher than the general population $[97,98]$, and also higher than in non-HH chronic liver disease patients [38]. Other co-factors including alcohol abuse, viral hepatitis and age over 55 years old increase risk of HCC in patients with $\mathrm{HH}$ [99]. Altogether, approximately $6 \%$ of males with $\mathrm{HH} 1.5 \%$ of females with HH develop HCC [38].

Iron can catalyse the degradation of $\mathrm{H}_{2} \mathrm{O}_{2}$ and $\mathrm{O}_{2}$ produced in mitochondria and other organelles, to $\mathrm{OH}$ via the Fenton and HaberWeiss reactions [100]. OH strongly damages DNA, protein and lipids, affecting the function of hepatocyte genes associated with tumour suppression, cell cycle regulation, DNA repair, and apoptosis. For example, approximate $70 \%$ of $\mathrm{HCC}$ case with $\mathrm{HH}$ showed mutations of tumour suppressor gene p53 [101,102]. In addition, Iron has been shown to enhance growth of human hepatoma cells [103].

\section{Aflatoxin $B_{1}$}

Aflatoxin $\mathrm{B}_{1}$ is produced by the soil fungus Aspergillus flavus, which contaminates foods such as peanuts, rice, soybeans, corn, and wheat if these are not properly stored [104]. Aflatoxin causes $4.6-28.2 \%$ of all global HCC cases, with most of these cases occurring in sub-Saharan Africa, Southeast Asia, and China [105]. In these regions, HBV infection is also endemic [106]. The risk of HCC is significantly higher in patients with aflatoxin exposure and HBV infection than patients with aflatoxin exposure without HBV $[107,108]$. A study demonstrated that HBV infection increases activation of the enzyme cytochrome $\mathrm{P} 450$ to convert aflatoxin to hepatocarcinogenic aflatoxin $\mathrm{B}_{1}-8,9$ epoxide [109]. HCV infection also enhances hepatocarcinogenesis of aflatoxin [110,111].

The hepatocarcinogenesis mechanisms of aflatoxin $B_{1}$ are not fully clear. Currently, it is believed that aflatoxin causes hepatocarcinogenesis via two pathways, i.e., direct reaction of aflatoxin with DNA; and oxidative stress resulting from immune responses induced by the aflatoxin. Aflatoxin B1 is oxidized by cytochrome P450 enzymes into aflatoxin $B_{1}-8,9$-epoxide [112], which can bind to DNA forming the aflatoxin $\mathrm{B}_{1}-\mathrm{N}^{7}-\mathrm{dG}$ DNA adduct [113]. This ultimately can lead to a $\mathrm{G}$ to $\mathrm{T}$ mutation at the third position of codon 249 of $\mathrm{p} 53$ tumour suppressor gene [114,115]. This mutation enhances hepatocyte dysplastic growth. In addition, a current study has demonstrated that aflatoxin B1, B2, G1 significantly increases releasing of cytokines from murine macrophages [116].

\section{Gender}

HCC cases occur $80 \%$ more in males than females [117]. The prevalence of HCC among males is higher than among females. It is estimated that worldwide, HCC is the fifth most prevalent cancer in men and the eighth in women [118], this varies depending on disease aetiology and geographic region [118]. For example, the male to female ratio of HCC in Thailand is 6.7:1[119], whereas this ratio is 4:1 in Egypt [120]. The frequency of HCC of Australian males was 3 times more than that of females [21].

The differences between men and women are attributed to genetic and environmental factors. Estrogen receptor- $\alpha$ is significantly expressed in chronic liver diseases and HCC [121]. Estrogens inhibits secretion of interleukin 6 by activated Kupffer cells [122], whereas interleukin-6 is an important pro-inflammatory factor [123]. Thus, estrogen may decrease risk of HCC through inhibiting liver inflammation, and provide a protective effect in women. Additionally, males are more likely than females to drink alcohol and smoke, which are associated with increased risk of HCC $[124,125]$. Additionally, smoking produces ROS [126].

\section{Obesity}

Obesity is a risk factor of HCC [127,128]. Incidences of HCC are rising with increasing of obesity prevalence [129]. The World Health Organization estimates that in 2000, at least 400 million adults were obese [130], while this was up to 1.5 billion in 2008 [131]. Obesity is a recognised risk factor for a range of cancers including oesophageal, stomach , colorectal, liver, gallbladder, pancreatic, prostate, and kidney cancer, non-Hodgkin's lymphoma, multiple myeloma, and leukaemia [128].

Obesity is considered a chronic inflammatory state that contributes to oxidative stress. Obesity is associated with elevated levels of inflammatory cytokines such as interleukin- 6 and tumour necrosis factor [132] (interleukin- 6 promotes hepatocarcinogenesis [122] while tumour necrosis factor regulates hepatocyte apoptosis [133]). Additionally, obesity elevates levels of oxidation products of protein and lipid, such as 4-hydroxynonenal [134], which in turn may be mutagenic [135].

\section{Age}

The incidence of hepatocellular carcinoma increases progressively with age. HCC rarely occurs in people less than 40 years old, except in some areas where hepatitis B virus infection is hyperendemic [4, 117]. In general, HCC patients are one to two decades younger in areas of high HCC incidence than in low incidence areas [4]. This may be because hepatitis $C$ and alcoholic cirrhosis typically occur late in life in low incidence areas; whereas, HBV infection, which is a major HCC risk factor, frequently occurs either at birth or during early childhood [16].

\section{Other known risk factors}

Other risk factors of HCC include tobacco smoking [136,137], $\alpha_{1}$ antitrypsin deficiency [138] and diabetes [139, 140]. It is still being debated whether the oral contraceptive pill increases the risk of developing HCC [141]. Tobacco smoking brings various carcinogens into bodies, inducing DNA damage [142], immune responses [143] and oxidative stress [144]. $\alpha_{1}$ antitrypsin deficiency, an autosomal dominant genetic disorder [145], induces inflammation [146]. Diabetes may accumulate free fatty acids and subsequently induce oxidation of lipid, increasing risks of fibrosis and cirrhosis [147,148].

\section{Conclusion}

HCC cases are more in developing countries than western 
developed countries, males than females, and elders than youths. The incidence of HCC is the highest among Asians; intermediate among African-Americans and Hispanics; and lowest rate among Caucasians. Most HCCs arise in cirrhosis whereas cirrhosis owns the same risk factors as HCC. Incidents of HCC are associated with its various risk factors. HBV and HCV are main risk factors of HCC. Studies indicate that viral DNA of $\mathrm{HBV}$ inserts into hepatocyte genome to induce genetic modification, and that the HBx protein can interfere with DNA repair, and with transcription and signalling pathways. Protein of $\mathrm{HCV}$ is perhaps involved in malignant transformation of hepatocytes. In addition, HCV infection causes oxidative stress to induce malignant transformation of hepatocyte. Other risk factors include alcohol, aflatoxin B1, iron overload, diabetes, non-alcoholic fatty liver disease, obesity, tobacco, vinyl chloride and thorium dioxide. Alcohol induces genotoxicity and oxidative stress. Oxidative product of Aflatoxin B1 perhaps cause a $\mathrm{G}$ to $\mathrm{T}$ mutation of $\mathrm{p} 53$ tumour suppressor. Iron can via the Fenton and Haber-Weiss reactions of $\mathrm{H}_{2} \mathrm{O}_{2}$ to produce $\mathrm{OH}$ that strongly damages DNA, protein and lipids of hepatocytes, leading to malignant transformations of hepatocytes. Estrogen receptor- $\alpha$ of women is involved in HCC. Obesity induces oxidative stress. Tobacco, vinyl chloride and thorium dioxide are genotoxicity. Risk factors also include some inherited metabolic diseases including hemochromatosis, tyrosinemia and $\alpha$-l-antitrypsin deficiency. The mechanisms of HCC are not completely known.

\section{Acknowledgments}

This review is revised from Chapter 2 Literature Review of my PhD thesis. I would like to thank the members of the Herston Health Science Library of the University of Queensland for their assistance.

\section{References}

1. Jemal A, Bray F, Center MM, Ferlay J, Ward E, et al. (2011) Global cancer statistics. CA Cancer J Clin 61: 69-90. [Crossref]

2. Kew MC (2002) Epidemiology of hepatocellular carcinoma. Toxicology 181-182: 358. [Crossref]

3. Yu AS, Keeffe EB (2003) Management of hepatocellular carcinoma. Rev Gastroenterol Disord 3: 8-24. [Crossref]

4. Bosch FX, Ribes J, Borràs J (1999) Epidemiology of primary liver cancer. Semin Liver Dis 19: 271-285. [Crossref]

5. Sohal DP, Sun W (2011) Hepatocellular carcinoma: prevention and therapy. Curr Oncol Rep 13: 186-194. [Crossref]

6. Feng GS (2012) Conflicting roles of molecules in hepatocarcinogenesis: paradigm or paradox. Cancer Cell 21: 150-154. [Crossref]

7. Cornellà H, Alsinet C, Villanueva A (2011) Molecular pathogenesis of hepatocellular carcinoma. Alcohol Clin Exp Res 35: 821-825. [Crossref]

8. Goodman ZD (2007) Neoplasms of the liver. Mod Pathol 20 Suppl 1: S49-60. [Crossref]

9. Ananthakrishnan A, Gogineni V, Saeian K (2006) Epidemiology of primary and secondary liver cancers. Semin Intervent Radiol 23: 47-63. [Crossref]

10. Lazaridis KN, Gores GJ (2005) Cholangiocarcinoma. Gastroenterology 128: 1655 1667. [Crossref]

11. Khan SA, Thomas HC, Davidson BR, Taylor-Robinson SD (2005) Cholangiocarcinoma. Lancet 366: 1303-1314. [Crossref]

12. El-Serag HB, Davila JA (2004) Is fibrolamellar carcinoma different from hepatocellular carcinoma? A US population-based study. Hepatology 39: 798-803. [Crossref]

13. Schnater JM, Köhler SE, Lamers WH, von Schweinitz D, Aronson DC (2003) Where do we stand with hepatoblastoma? A review. Cancer 98: 668-678. [Crossref]

14. Monga SPS (2011) Biology of Metastatic Liver Tumors, in Molecular Pathology of Liver Diseases. Springer US. 859-866.
15. Okuda K (2000) Hepatocellular carcinoma. J Hepatol 32: 225-237. [Crossref]

16. El-Serag HB (2002) Hepatocellular carcinoma: an epidemiologic view. $J$ Clin Gastroenterol 35: S72-78. [Crossref]

17. Bosch FX, Ribes J, Cléries R, Díaz M (2005) Epidemiology of hepatocellular carcinoma. Clin Liver Dis 9: 191-211. [Crossref]

18. Yuen MF, Hou JL, Chutaputti A (2009) Asia Pacific Working Party on Prevention of Hepatocellular Carcinoma Hepatocellular carcinoma in the Asia pacific region. $J$ Gastroenterol Hepatol 24: 346-353. [Crossref]

19. Van Rensburg SJ, Cook-Mozaffari P, Van Schalkwyk DJ, Van der Watt JJ, Vincent TJ, et al. (1985) Hepatocellular carcinoma and dietary aflatoxin in Mozambique and Transkei. Br J Cancer 51: 713-726. [Crossref]

20. Montalto G, Cervello M, Giannitrapani L, Dantona F, Terranova A, et al. (2002) Epidemiology, risk factors, and natural history of hepatocellular carcinoma. Ann N Y Acad Sci 963: 13-20. [Crossref]

21. Prosselkova G (2012) Cancer survival and prevalence in Australia: period estimates from 1982 to 2010. Canberra, A.C.T: Australian Institute of Health and Welfare.

22. Schutte KJ, Bornschein J, Malfertheiner P (2009) Hepatocellular Carcinoma Epidemiological Trends and Risk Factors. Digestive Diseases 27: 80-92. [Crossref].

23. Thun MJ, DeLancey JO, Center MM, Jemal A, Ward EM (2010) The global burden of cancer: priorities for prevention. Carcinogenesis 31: 100-110. [Crossref]

24. El-Serag HB (2002) Hepatocellular carcinoma: an epidemiologic view. $J$ Clin Gastroenterol 35: S72-78. [Crossref]

25. Blumberg BS, Larouzé B, London WT, Werner B, Hesser JE, et al. (1975) The relation of infection with the hepatitis B agent to primary hepatic carcinoma. Am J Pathol 81: 669-682. [Crossref]

26. Tsukuma H, Hiyama T, Tanaka S, Nakao M, Yabuuchi T, et al. (1993) Risk factors for hepatocellular carcinoma among patients with chronic liver disease. N Engl J Med 328 : 1797-1801. [Crossref]

27. Lubrano J, Huet E, Tsilividis B, François A, Goria O, et al. (2008) Long-Term Outcome of Liver Resection for Hepatocellular Carcinoma in Noncirrhotic Nonfibrotic Liver with No Viral Hepatitis or Alcohol Abuse. World Journal of Surgery 32: 104-109. [Crossref]

28. Stroffolini T, Andreone P, Andriulli A, Ascione A, Craxi A, et al. (1998) Characteristics of hepatocellular carcinoma in Italy. J Hepatol 29: 944-952. [Crossref]

29. Grando-Lemaire V, Guettier C, Chevret S, Beaugrand M, Trinchet JC, et al. (1999) Hepatocellular carcinoma without cirrhosis in the West: epidemiological factors and histopathology of the non-tumorous liver. Journal of Hepatology 31: 508-513. [Crossref]

30. Lavanchy D (2004) Hepatitis B virus epidemiology, disease burden, treatment, and current and emerging prevention and control measures. Journal of Viral Hepatitis 11: 97-107. [Crossref]

31. Simonetti RG, Cammà C, Fiorello F, Politi F, D'Amico G, et al. (1991) Hepatocellular carcinoma. A worldwide problem and the major risk factors. Dig Dis Sci 36: 962-972. [Crossref]

32. Koike K (2007) Hepatitis C virus contributes to hepatocarcinogenesis by modulating metabolic and intracellular signaling pathways. J Gastroenterol Hepatol 22 Suppl 1: S108-111. [Crossref]

33. Dominguez-Malagón H, Gaytan-Graham S (2001) Hepatocellular carcinoma: an update. Ultrastruct Pathol 25: 497-516. [Crossref]

34. Lim YS, Kim WR (2008) The global impact of hepatic fibrosis and end-stage liver disease. Clin Liver Dis 12: 733-746. [Crossref]

35. Everhart JE, Ruhl CE (2009) Burden of digestive diseases in the United States Part III Liver, biliary tract, and pancreas. Gastroenterology 136: 1134-1144. [Crossref]

36. Polesel J, Zucchetto A, Montella M, Dal Maso L, Crispo A, et al. (2009) The impact of obesity and diabetes mellitus on the risk of hepatocellular carcinoma. Ann Oncol 20: 353-357. [Crossref]

37. Byrne CD, Wild SH (2010) Body fat and increased risk of cirrhosis. BMJ 340: c774 [Crossref]

38. Fracanzani AL, Conte D, Fraquelli M, Taioli E, Mattioli M, et al. (2001) Increased cancer risk in a cohort of 230 patients with hereditary hemochromatosis in comparison to matched control patients with non-iron-related chronic liver disease. Hepatology 33: 647-651. [Crossref] 
39. Migita K, Watanabe Y, Jiuchi Y, Nakamura Y, Saito A, et al. (2011) Evaluation of risk factors for the development of cirrhosis in autoimmune hepatitis: Japanese NHO-AIH prospective study. J Gastroenterol 46 Suppl 1: 56-62. [Crossref]

40. Perz JF, Armstrong GL, Farrington LA, Hutin YJ, Bell BP (2006) The contributions of hepatitis $\mathrm{B}$ virus and hepatitis $\mathrm{C}$ virus infections to cirrhosis and primary liver cancer worldwide. J Hepatol 45: 529-538. [Crossref]

41. Maupas P, Werner B, Larouzé B, Millman I, London WT, et al. (1975) Antibody to hepatitis-B core antigen in patients with primary hepatic carcinoma. Lancet 2: 9-11. [Crossref]

42. Sherlock S, Fox RA, Niazi SP, Scheuer PJ (1970) Chronic liver disease and primary liver-cell cancer with hepatitis-associated (Australia) antigen in serum. Lancet 1: 12431247. [Crossref]

43. Beasley RP, Hwang LY, Lin CC, Chien CS (1981) Hepatocellular carcinoma and hepatitis B virus. A prospective study of 22707 men in Taiwan. Lancet 2: 1129-1133. [Crossref]

44. Organization, W.H., Hepatitis B, .Organization Fact Sheet 204 (Revised October 2000). 2000.

45. Yu MC, Yuan JM, Govindarajan S, Ross RK (2000) Epidemiology of hepatocellular carcinoma. Can J Gastroenterol 14: 703-709. [Crossref]

46. Chang MH, Chen CJ, Lai MS, Hsu HM, Wu TC, et al. (1997) Universal hepatitis $B$ vaccination in Taiwan and the incidence of hepatocellular carcinoma in children. Taiwan Childhood Hepatoma Study Group. N Engl J Med 336: 1855-1859. [Crossref]

47. Liaw YF, Sung JJ, Chow WC, Farrell G, Lee CZ, et al. (2004) Lamivudine for patients with chronic hepatitis B and advanced liver disease. N Engl J Med 351: 1521-1531. [Crossref]

48. Rabe C, Cheng B, Caselmann WH (2001) Molecular mechanisms of hepatitis B virusassociated liver cancer. Dig Dis 19: 279-287. [Crossref]

49. Kay A, Zoulim F (2007) Hepatitis B virus genetic variability and evolution. Virus Res 127: 164-176. [Crossref]

50. Lau JY, Wright TL (1993) Molecular virology and pathogenesis of hepatitis B. Lancet 342: 1335-1340. [Crossref]

51. Murakami S (1999) Hepatitis B virus X protein: structure, function and biology. Intervirology 42: 81-99. [Crossref]

52. Brechot C, Pourcel C, Louise A, Rain B, Tiollais P (1980) Presence of integrated hepatitis B virus DNA sequences in cellular DNA of human hepatocellular carcinoma. Nature 286: 533-535. [Crossref]

53. Shafritz DA, Shouval D, Sherman HI, Hadziyannis SJ, Kew MC (1981) Integration of hepatitis B virus DNA into the genome of liver cells in chronic liver disease and hepatocellular carcinoma. Studies in percutaneous liver biopsies and post-mortem tissue specimens. N Engl J Med 305: 1067-1073. [Crossref]

54. Bonilla Guerrero R, Roberts LR (2005) The role of hepatitis B virus integrations in the pathogenesis of human hepatocellular carcinoma. J Hepatol 42: 760-777. [Crossref]

55. Dandri M, Burda MR, Bürkle A, Zuckerman DM, Will H, et al. (2002) Increase in de novo HBV DNA integrations in response to oxidative DNA damage or inhibition of poly(ADP-ribosyl)ation. Hepatology 35: 217-223. [Crossref]

56. Feitelson MA, Lee J (2007) Hepatitis B virus integration, fragile sites, and hepatocarcinogenesis. Cancer Lett 252: 157-170. [Crossref]

57. Murakami Y, Saigo K, Takashima H, Minami M, Okanoue T, et al. (2005) Large scaled analysis of hepatitis B virus (HBV) DNA integration in HBV related hepatocellular carcinomas. Gut 54: 1162-1168. [Crossref]

58. Becker SA, Lee TH, Butel JS, Slagle BL (1998) Hepatitis B virus X protein interferes with cellular DNA repair. J Virol 72: 266-272. [Crossref]

59. Muroyama R, Kato N, Yoshida H, Otsuka M, Moriyama M, et al. (2006) Nucleotide change of codon 38 in the $\mathrm{X}$ gene of hepatitis $\mathrm{B}$ virus genotype $\mathrm{C}$ is associated with an increased risk of hepatocellular carcinoma. J Hepatol 45: 805-812. [Crossref]

60. Di Bisceglie AM, Lyra AC, Schwartz M, Reddy RK, Martin P, et al. (2003) Hepatitis $\mathrm{C}$-related hepatocellular carcinoma in the United States: influence of ethnic status. $\mathrm{Am}$ J Gastroenterol 98: 2060-2063. [Crossref]

61. Mondragón-Sánchez R, Garduño-López AL, Hernández-Castillo E, Gómez-Gómez E, Ruiz-Molina JM (2005) Hepatocellular carcinoma and hepatitis C in Mexico. Hepatogastroenterology 52: 1159-1162. [Crossref]
62. Stroffolini T, Sagnelli E, Mele A, Almasio P (2005) Trends of aetiological factors of hepatocellular carcinoma in Italy. Dig Liver Dis 37: 985-986. [Crossref]

63. Sagnelli E, Stroffolini T, Mele A, Almasio P, Coppola N, et al. (2005) The importance of $\mathrm{HCV}$ on the burden of chronic liver disease in Italy: a multicenter prevalence study of 9,997 cases. J Med Virol 75: 522-527. [Crossref]

64. Garcia-Torres ML, Zaragozá A, Giner R, Primo J, del Olmo JA. (2003) Incidence and epidemiological factors of hepatocellular carcinoma in Valencia during the year 2000 Revista Espanola De Enfermedades Digestivas 95: 385-388. [Crossref]

65. Dohmen, K, Shigematsu H, Irie K, Ishibashi H (2003) Trends in Clinical Characteristics, Treatment and Prognosis of Hepatocellular Carcinoma. Hepato-Gastroenterology 50: 1872-1877. [Crossref]

66. Alter MJ (1997) Epidemiology of hepatitis C. Hepatology 26: 62S-65S. [Crossref]

67. Lavanchy D (2008) Chronic viral hepatitis as a public health issue in the world. Best Practice \& Research Clinical Gastroenterology 22: 991-1008. [Crossref]

68. Armstrong GL, Wasley A, Simard EP, McQuillan GM, Kuhnert WL, et al. (2006) The prevalence of hepatitis C virus infection in the United States, 1999 through 2002. Ann Intern Med 144: 705-714. [Crossref]

69. Bellentani S, Tiribelli C (2001) The spectrum of liver disease in the general population lesson from the Dionysos study. J Hepatol 35: 531-537. [Crossref]

70. Wiese M, Berr F, Lafrenz M, Porst H, Oesen U (2000) Low frequency of cirrhosis in a hepatitis C (genotype $1 \mathrm{~b}$ ) single-source outbreak in germany: a 20 -year multicenter study. Hepatology 32: 91-96. [Crossref]

71. Dutta U, Byth K, Kench J, Khan MH, Coverdale SA, et al. (1999) Risk factors for development of hepatocellular carcinoma among Australians with hepatitis C: a casecontrol study. Aust NZJ Med 29: 300-307. [Crossref]

72. Cho LY, Yang JJ, Ko KP, Park B, Shin A, et al. (2011) Coinfection of hepatitis B and C viruses and risk of hepatocellular carcinoma: systematic review and meta-analysis. Int J Cancer 128: 176-184. [Crossref]

73. Sun J, Chaturvedi G, Weinman AS, et al. (2011) Viral Hepatitis C, in Molecular Pathology of Liver Diseases. Springer US: 569-588.

74. The Kirby Institute (2012) HIV, viral hepatitis and sexually transmissible infections in Australia Annual Surveillance Report 2012. The Kirby Institute, the University of New South Wales: Sydney.

75. Tellinghuisen TL, Rice CM (2002) Interaction between hepatitis $C$ virus proteins and host cell factors. Curr Opin Microbiol 5: 419-427. [Crossref]

76. Choo QL, Kuo G, Weiner AJ, Overby LR, Bradley DW, et al. (1989) Isolation of a cDNA clone derived from a blood-borne non-A, non-B viral hepatitis genome. Science 244: 359-362. [Crossref]

77. Penin F, Dubuisson J, Rey FA, Moradpour D, Pawlotsky JM (2004) Structural biology of hepatitis C virus. Hepatology 39: 5-19. [Crossref]

78. Levrero M (2006) Viral hepatitis and liver cancer: the case of hepatitis C. Oncogene 25: 3834-3847. [Crossref]

79. Parola M, Robino G (2001) Oxidative stress-related molecules and liver fibrosis. $J$ Hepatol 35: 297-306. [Crossref]

80. Allen NE, Beral V, Casabonne D, Kan SW, Reeves GK, et al. (2009) Moderate alcoho intake and cancer incidence in women. J Natl Cancer Inst 101: 296-305. [Crossref]

81. IARC (1988) Working Group on the Evaluation of Carcinogenic Risks to Humans, IARC monographs on the evaluation of carcinogenic risks to humans. Alcohol drinking. 44. Lyon: International Agency for Research on Cancer.

82. Donato F, Tagger A, Gelatti U, Parrinello G, Boffetta P, et al. (2002) Alcohol and hepatocellular carcinoma: the effect of lifetime intake and hepatitis virus infections in men and women. Am J Epidemiol 155: 323-331. [Crossref]

83. Chen CJ, Liang KY, Chang AS, Chang YC, Lu SN, et al. (1991) Effects of hepatitis $\mathrm{B}$ virus, alcohol drinking, cigarette smoking and familial tendency on hepatocellular carcinoma. Hepatology 13: 398-406. [Crossref]

84. Hassan MM, Hwang LY, Hatten CJ, Swaim M, Li D, et al. (2002) Risk factors for hepatocellular carcinoma: synergism of alcohol with viral hepatitis and diabetes mellitus. Hepatology 36: 1206-1213. [Crossref]

85. Lauret E, Rodríguez M, González S, Linares A, López-Vázquez A, et al. (2002) HFE gene mutations in alcoholic and virus-related cirrhotic patients with hepatocellular carcinoma. Am J Gastroenterol 97: 1016-1021. [Crossref]

86. Rehm J, et al. (2004) Alcohol us. Geneva: World Health Organization. 
87. Lieber CS (2004) Alcoholic fatty liver: its pathogenesis and mechanism of progression to inflammation and fibrosis. Alcohol 34: 9-19. [Crossref]

88. Fraenkel-Conrat H, Singer B (1988) Nucleoside Adducts are Formed by Cooperative Reaction of Acetaldehyde and Alcohols: Possible Mechanism for the Role of Ethanol in Carcinogenesis. Proc Natl Acad Sci USA 85: 3758-3761. [Crossref]

89. Choi SW, Stickel F, Baik HW, Kim YI, Seitz HK, et al. (1999) Chronic alcohol consumption induces genomic but not p53-specific DNA hypomethylation in rat colon. J Nutr 129: 1945-1950. [Crossref]

90. Garro AJ, McBeth DL, Lima V, Lieber CS (1991) Ethanol Consumption Inhibits Fetal DNA Methylation in Mice: Implications for the Fetal Alcohol Syndrome. Alcoholism: Clinical and Experimental Research 15: 395-398. [Crossref]

91. Bautista AP (2002) Neutrophilic infiltration in alcoholic hepatitis. Alcohol 27: 17-21. [Crossref]

92. Chamulitrat W, Spitzer JJ (1996) Nitric Oxide and Liver Injury in Alcohol-Fed Rats after Lipopolysaccharide Administration. Alcoholism: Clinical and Experimental Research 20: 1065-1070. [Crossref]

93. McClain CJ, Cohen DA (1989) Increased tumor necrosis factor production by monocytes in alcoholic hepatitis. Hepatology 9: 349-351. [Crossref]

94. Bacon BR, Powell LW, Adams PC, Kresina TF, Hoofnagle JH (1999) Molecular medicine and hemochromatosis: at the crossroads. Gastroenterology 116: 193-207. [Crossref]

95. Merryweather-Clarke AT, Pointon JJ, Jouanolle AM, Rochette J, Robson KJ (2000) Geography of HFE C282Y and H63D mutations. Genet Test 4: 183-198. [Crossref]

96. Leggett BA, Halliday JW, Brown NN, Bryant S, Powell LW (1990) Prevalence of haemochromatosis amongst asymptomatic Australians. Br J Haematol 74: 525-530. [Crossref]

97. Hsing AW, McLaughlin JK, Olsen JH, Mellemkjar L, Wacholder S, et al. (1995) Cancer risk following primary hemochromatosis: a population-based cohort study in Denmark. Int J Cancer 60: 160-162. [Crossref]

98. Elmberg M, Hultcrantz R, Ekbom A, Brandt L, Olsson S, et al. (2003) Cancer risk in patients with hereditary hemochromatosis and in their first-degree relatives. Gastroenterology 125: 1733-1741. [Crossref]

99. Fargion S, Fracanzani AL, Piperno A, Braga M, D’Alba R, et al. (1994) Prognostic factors for hepatocellular carcinoma in genetic hemochromatosis. Hepatology 20: 1426-1431. [Crossref]

100. Halliwell B, Gutteridge JM (1986) Oxygen free radicals and iron in relation to biology and medicine: some problems and concepts. Arch Biochem Biophys 246: 501-514. [Crossref]

101. Marrogi AJ, Khan MA, van Gijssel HE, Welsh JA, Rahim H, et al. (2001) Oxidative Stress and p53 Mutations in the Carcinogenesis of Iron Overload-Associated Hepatocellular Carcinoma. Journal of the National Cancer Institute 93: 1652-1655. [Crossref]

102. Vautier G, Bomford AB, Portmann BC, Metivier E, Williams R, et al. (1999) p53 mutations in British patients with hepatocellular carcinoma: Clustering in genetic hemochromatosis. Gastroenterology 117: 154-160.

103. Hann HW, Stahlhut MW, Hann CL (1990) Effect of iron and desferoxamine on cell growth and in vitro ferritin synthesis in human hepatoma cell lines. Hepatology 11: 566-569. [Crossref]

104. Gourama H, Bullerman LB (1995) Aspergillus flavus and Aspergillus parasiticus: Aflatoxigenic Fungi of Concern in Foods and Feeds: A Review. Journal of Food Protection 58: 1395-1404

105. Liu Y, Wu F (2010) Global burden of aflatoxin-induced hepatocellular carcinoma: a risk assessment. Environ Health Perspect 118: 818-824. [Crossref]

106. Wild CP, Gong YY (2010) Mycotoxins and human disease: a largely ignored global health issue. Carcinogenesis 31: 71-82. [Crossref]

107. Wang LY, Hatch M, Chen CJ, Levin B, You SL, et al. (1996) Aflatoxin exposure and risk of hepatocellular carcinoma in Taiwan. Int J Cancer 67: 620-625. [Crossref]

108. Kew MC (2003) Synergistic interaction between aflatoxin B1 and hepatitis B virus in hepatocarcinogenesis. Liver Int 23: 405-409. [Crossref]

109. Gemechu-Hatewu M, Platt KL, Oesch F, Hacker HJ, Bannasch P, et al. (1997) Metabolic activation of aflatoxin B1 to aflatoxin B1-8,9-epoxide in woodchucks undergoing chronic active hepatitis. International Journal of Cancer 73: 587-591. [Crossref]
110. Chen CH, Wang MH, Wang JH, Hung CH, Hu TH, et al. (2007) Aflatoxin exposure and hepatitis $\mathrm{C}$ virus in advanced liver disease in a hepatitis $\mathrm{C}$ virus endemic area in Taiwan. Am J Trop Med Hyg 77: 747-752. [Crossref]

111. Jeannot E, Boorman GA, Kosyk O, Bradford BU, Shymoniak S, et al. (2012) Increased incidence of aflatoxin B1-induced liver tumors in hepatitis virus $\mathrm{C}$ transgenic mice. Int J Cancer 130: 1347-1356. [Crossref]

112. Ueng YF, Shimada T, Yamazaki H, Guengerich FP (1995) Oxidation of aflatoxin B1 by bacterial recombinant human cytochrome P450 enzymes. Chem Res Toxicol 8: 218-225. [Crossref]

113. Iyer RS, et al. (1994) DNA Adduction by the Potent Carcinogen Aflatoxin B1 Mechanistic Studies. Journal of the American Chemical Society 116: 1603-1609.

114. Smela ME, Hamm ML, Henderson PT, Harris CM, Harris TM, et al. (2002) The aflatoxin B1 formamidopyrimidine adduct plays a major role in causing the types of mutations observed in human hepatocellular carcinoma. Proc Natl Acad Sci USA 99: 6655-6660. [Crossref]

115. Smela ME, Currier SS, Bailey EA, Essigmann JM (2001) The chemistry and biology of aflatoxin $\mathrm{B}(1)$ : from mutational spectrometry to carcinogenesis. Carcinogenesis 22: 535-545. [Crossref]

116. Bruneau J, Loscher C, and O'Kennedy R (2009) Investigation of the ImmunoModulatory Effects of Aflatoxin B1, B2 and G1. Epidemiology 20: S42-S43.

117. Schiff ER, Willis MFS, Maddrey C (1999) Chapter 55: Malignant Neoplasms of the liver, in Schiff's Diseases of the liver.

118. Parkin DM, Bray F, Ferlay J, Pisani P (2005) Global cancer statistics, 2002. CA Cancer J Clin 55: 74-108. [Crossref]

119. Tangkijvanich P, Mahachai V, Suwangool P, Poovorawan Y (2004) Gender difference in clinicopathologic features and survival of patients with hepatocellular carcinoma. World J Gastroenterol 10: 1547-1550. [Crossref]

120. Lehman EM, Soliman AS, Ismail K, Hablas A, Seifeldin IA, et al. (2008) Patterns of hepatocellular carcinoma incidence in Egypt from a population-based cancer registry. Hepatology Research 38: 465-473. [Crossref]

121. Iavarone M, Lampertico P, Seletti C, Francesca Donato M, Ronchi G, et al. (2003) The clinical and pathogenetic significance of estrogen receptor- $\beta$ expression in chronic liver diseases and liver carcinoma. Cancer 98: 529-534. [Crossref]

122. Naugler WE, Sakurai T, Kim S, Maeda S, Kim K, et al. (2007) Gender disparity in liver cancer due to sex differences in MyD88-dependent IL-6 production. Science 317: 121-124. [Crossref]

123. Naugler WE, Karin M (2008) The wolf in sheep's clothing: the role of interleukin-6 in immunity, inflammation and cancer. Trends in Molecular Medicine 14: 109-119. [Crossref]

124. Ogimoto I, Shibata A, Kurozawa Y, Nose T, Yoshimura T, et al. (2004) Risk of death due to hepatocellular carcinoma among drinkers and ex-drinkers. Univariate analysis of JACC study data. Kurume Med J 51: 59-70. [Crossref]

125. Yu MC, Yuan JM (2004) Environmental factors and risk for hepatocellular carcinoma Gastroenterology 127: S72-78. [Crossref]

126. Talukder MA, Johnson WM, Varadharaj S, Lian J, Kearns PN, et al. (2011) Chronic cigarette smoking causes hypertension, increased oxidative stress, impaired $\mathrm{NO}$ bioavailability, endothelial dysfunction, and cardiac remodeling in mice. American Journal of Physiology - Heart and Circulatory Physiology 300: H388-H396. [Crossref]

127. Nair S, Mason A, Eason J, Loss G, Perrillo RP (2002) Is obesity an independent risk factor for hepatocellular carcinoma in cirrhosis? Hepatology 36: 150-155. [Crossref]

128. Calle EE, Rodriguez C, Walker-Thurmond K, Thun MJ (2003) Overweight, obesity, and mortality from cancer in a prospectively studied cohort of U.S. adults. $N$ Engl J Med 348: 1625-1638. [Crossref]

129. Saunders D, Seidel D, Allison M, Lyratzopoulos G (2010) Systematic review: the association between obesity and hepatocellular carcinoma - epidemiological evidence. Alimentary Pharmacology \& Therapeutics 31: 1051-1063. [Crossref]

130. WHO (2000) Obesity: preventing and managing the global epidemic. Report of a WHO consultation. World Health Organization - Technical Report Series 894: 1-253.

131. WHO (2011) Obesity and overweight.

132. Park EJ, Lee JH, Yu GY, He G, Ali SR, et al. (2010) Dietary and genetic obesity promote liver inflammation and tumorigenesis by enhancing IL-6 and TNF expression. Cell 140: 197-208. [Crossref] 
133. Schwabe RF, Brenner DA (2006) Mechanisms of Liver Injury. I. TNF-alpha-induced liver injury: role of IKK, JNK, and ROS pathways. Am J Physiol Gastrointest Liver Physiol 290: G583-589. [Crossref]

134. Russell AP, Gastaldi G, Bobbioni-Harsch E, Arboit P, Gobelet C, et al. (2003) Lipid peroxidation in skeletal muscle of obese as compared to endurance-trained humans: a case of good vs. bad lipids? FEBS Lett 551: 104-106. [Crossref]

135. Hu W, Feng Z, Eveleigh J, Iyer G, Pan J, et al. (2002) The major lipid peroxidation product, trans-4-hydroxy-2-nonenal, preferentially forms DNA adducts at codon 249 of human p53 gene, a unique mutational hotspot in hepatocellular carcinoma. Carcinogenesis 23: 1781-1789. [Crossref]

136. Tanaka K, Tanaka K, Tsuji I, Wakai K, Nagata C, et al. (2006) Cigarette Smoking and Liver Cancer Risk: An Evaluation Based on a Systematic Review of Epidemiologic Evidence among Japanese. Japanese Journal of Clinical Oncology 36: 445-456. [Crossref]

137. Lee YC, Cohet C, Yang YC, Stayner L, Hashibe M, et al. (2009) Meta-analysis of epidemiologic studies on cigarette smoking and liver cancer. Int J Epidemiol 38: 1497-1511. [Crossref]

138. Eriksson S, Carlson J, Velez R (1986) Risk of cirrhosis and primary liver cancer in alpha 1-antitrypsin deficiency. N Engl J Med 314: 736-739. [Crossref]

139. El-Serag HB, Hampel H, Javadi F (2006) The Association Between Diabetes and Hepatocellular Carcinoma: A Systematic Review of Epidemiologic Evidence. Clinical Gastroenterology and Hepatology 4: 369-380. [Crossref]
140. El-Serag HB, Tran T, Everhart JE (2004) Diabetes increases the risk of chronic liver disease and hepatocellular carcinoma. Gastroenterology 126: 460-468. [Crossref]

141. Maheshwari S, Sarraj A, Kramer J, El-Serag HB (2007) Oral contraception and the risk of hepatocellular carcinoma. J Hepatol 47: 506-513. [Crossref]

142. Dube MF, Green CR (1982) Recent advances in tobacco science: Methods of collecting of smoke for analytical purposes. 36th Tobacco Chemists Research Conference. Symposium on the Formation, Analysis and Composition of Tobacco Smoke 42-102.

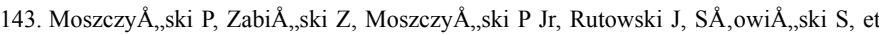
al. (2001) Immunological findings in cigarette smokers. Toxicol Lett 118: 121-127. [Crossref]

144. Valavanidis A, Vlachogianni T, and Fiotakis K (2009) Tobacco Smoke: Involvement of Reactive Oxygen Species and Stable Free Radicals in Mechanisms of Oxidative Damage, Carcinogenesis and Synergistic Effects with Other Respirable Particles. International Journal of Environmental Research and Public Health 6: 445-462. [Crossref]

145. Sifers RN, Finegold MJ, Woo SL (1992) Molecular biology and genetics of alpha 1-antitrypsin deficiency. Semin Liver Dis 12: 301-310. [Crossref]

146. Teckman JH, Qu D, Perlmutter DH (1996) Molecular pathogenesis of liver disease in alpha1-antitrypsin deficiency. Hepatology 24: 1504-1516. [Crossref]

147. Farrell GC, Larter CZ (2006) Nonalcoholic fatty liver disease: from steatosis to cirrhosis. Hepatology 43: S99-99S112. [Crossref]

148. Adams LA, Angulo P (2005) Recent concepts in non-alcoholic fatty liver disease. Diabet Med 22: 1129-1133. [Crossref]

Copyright: (C2016 Lu MLRY. This is an open-access article distributed under the terms of the Creative Commons Attribution License, which permits unrestricted use, distribution, and reproduction in any medium, provided the original author and source are credited. 